\title{
In situ S/TEM Reduction Reaction of Calcined Cu/BEA-zeolite Catalyst
}

\author{
Kinga A. Unocic ${ }^{1}$, Daniel A. Ruddy ${ }^{2}$, Theodore R. Krause ${ }^{3}$ and Susan Habas ${ }^{2}$ \\ 1. Materials Science \& Technology Division, Oak Ridge National Laboratory, Oak Ridge, TN, USA. \\ 2. National Bioenergy Center, National Renewable Energy Laboratory, Golden, CO, USA. \\ 3. Chemical Sciences and Engineering, Argonne National Laboratory, Argonne, IL, USA.
}

Zeolite-catalyzed processes represent promising approaches to convert $\mathrm{C}_{1}$ species (e.g., methanol, dimethyl ether (DME)) from syngas into targeted classes of high-value fuels and chemicals. H-BEA, large pore acidic zeolites, can be used to convert methanol and/or DME to branched $\mathrm{C}_{4}-\mathrm{C}_{7}$ alkanes with high selectivity to isobutane and 2,2,3-Trimethylbutane [1,2]. Recent research has demonstrated that the addition of $\mathrm{Cu}$ to the BEA zeolite catalyst can further improve hydrocarbon productivity by incorporation of co-fed $\mathrm{H}_{2}$ into the desired products [3]. Advanced catalyst synthesis coupled with advanced characterization are key to advancing catalyst research and development; thus, to better understand the mechanism of $\mathrm{Cu}$ species incorporation into the BEA zeolite, high-resolution and in situ scanning transmission electron microscopy (S/TEM) are being used to provide insight.

In situ closed gas cell microscopy can be utilized to study a range of material systems in response to temperature and reactant gases. In situ STEM allow for exposures of catalysts at temperatures up to $1000^{\circ} \mathrm{C}$ and pressures up to $1 \mathrm{~atm}$ [4]. In the present work, in situ microscopy exposure of the $\mathrm{Cu} / \mathrm{BEA}$ catalysts in air at $300^{\circ} \mathrm{C}$ will be correlated with results from similar experiments performed using an ex situ lab-scale reactor system (results not included here). The $\mathrm{Cu} / \mathrm{BEA}$ catalysts were prepared by an incipient wetness method by adding $\mathrm{Cu}\left(\mathrm{NO}_{3}\right)_{2} \cdot 2.5 \mathrm{H}_{2} \mathrm{O}$ to ammonium beta zeolite $\left(\mathrm{NH}_{4}\right.$-BEA) powder with $\mathrm{SiO}_{2} / \mathrm{Al}_{2} \mathrm{O}_{3}$ ratio of 27 [5]. The actual $\mathrm{Cu}$ loading was measured to be 4.3 wt.\%. The $\mathrm{Cu} / \mathrm{BEA}$ catalyst was activated in flowing air $\left(10 \% \mathrm{O}_{2} / \mathrm{Ar}\right.$ ) heated at $2{ }^{\circ} \mathrm{C} / \mathrm{min}$ to $500^{\circ} \mathrm{C}$ and held for $5 \mathrm{~h}$ (calcined $\mathrm{Cu} / \mathrm{BEA}$ ), which was the final material used for the in situ $\mathrm{S} / \mathrm{TEM}$ experiments.

The calcined $\mathrm{Cu} / \mathrm{BEA}$ particles were mixed in hexane in air and crushed to fit in the $5 \mu \mathrm{m}$ gas-flow gap of the cell [4]. A droplet of the suspension was placed on the silicon nitride window of a Protochips ${ }^{\mathrm{TM}}$ E-chip heater chip. A Protochip Atmosphere ${ }^{\mathrm{TM}}$ gas reaction holder was used for the in situ STEM experiments, which were conducted using an aberration-corrected JEOL 2200FS operated at 200kV. The gas-cell was flushed three times with nitrogen at 50 Torr to ensure there was no $\mathrm{O}_{2}$ present in the system. The pressure was then set to 720 Torr, the gas-cell was filled with $4 \% \mathrm{H}_{2} / \mathrm{Ar}$, and the temperature was ramped up at a rate of $30^{\circ} \mathrm{C} / \mathrm{min} .\left(0.5^{\circ} \mathrm{C} / \mathrm{sec}\right)$ from $\mathrm{RT}$ to $300^{\circ} \mathrm{C}$ under flowing $4 \% \mathrm{H}_{2} / \mathrm{Ar}$. No significant change in the morphology of the catalyst particles was observed while the temperature was increasing; however, fine-scale precipitates were clearly observed after holding the catalyst for $14 \mathrm{~min}$. at $300^{\circ} \mathrm{C}$ (Figure 2) and their size increased with further exposure time (2h total) at $300^{\circ} \mathrm{C}$. Energy dispersive X-ray spectroscopy (EDS) elemental analysis after exposure in $4 \% \mathrm{H}_{2} / \mathrm{Ar}$ for $2 \mathrm{~h}$ at $300^{\circ} \mathrm{C}$ confirmed that the precipitation observed was primarily associated with $\mathrm{Cu}$. Changes in the Al distribution was also observed. These initial observations suggest segregation of Al into small culsters in addition to $\mathrm{Cu}$-rich precipitate formation, which requires further confirmation. The in situ $\mathrm{S} / \mathrm{TEM}$ results agree with lab-scale experiments [3]. The validation of in situ S/TEM capabilities can enable future identification of active sites and catalyst regeneration procedures [5].

References: 
[1] J H Ahn, B Temel, E Iglesia, Angew. Chem. Int. Ed. 48, (2009) p. 3814.

[2] N Hazari et al, Accounts Chem. Res. 45 (2012), p. 653.

[3] J A Schaidle et al, ACS Catal. 5 (2015), p. 1794.

[4] K A Unocic et al, Oxid. Metals on line (2017), p.1.

[5] This work was performed in collaboration with the Chemical Catalysis for Bioenergy Consortium (ChemCatBio), a member of the Energy Materials Network (EMN), and supported by the U.S. DOE Bioenergy Technology Office under Contract no DE-AC05-00OR22725 (ORNL), Contract no. DEAC36-08-GO28308 (NREL), and Contract no. DE-AC02-06CH11357 (ANL). Microscopy performed as part of a user project at the Center for Nanophase Materials Sciences (CNMS), which is a U.S. DOE Office of Science User Facility.
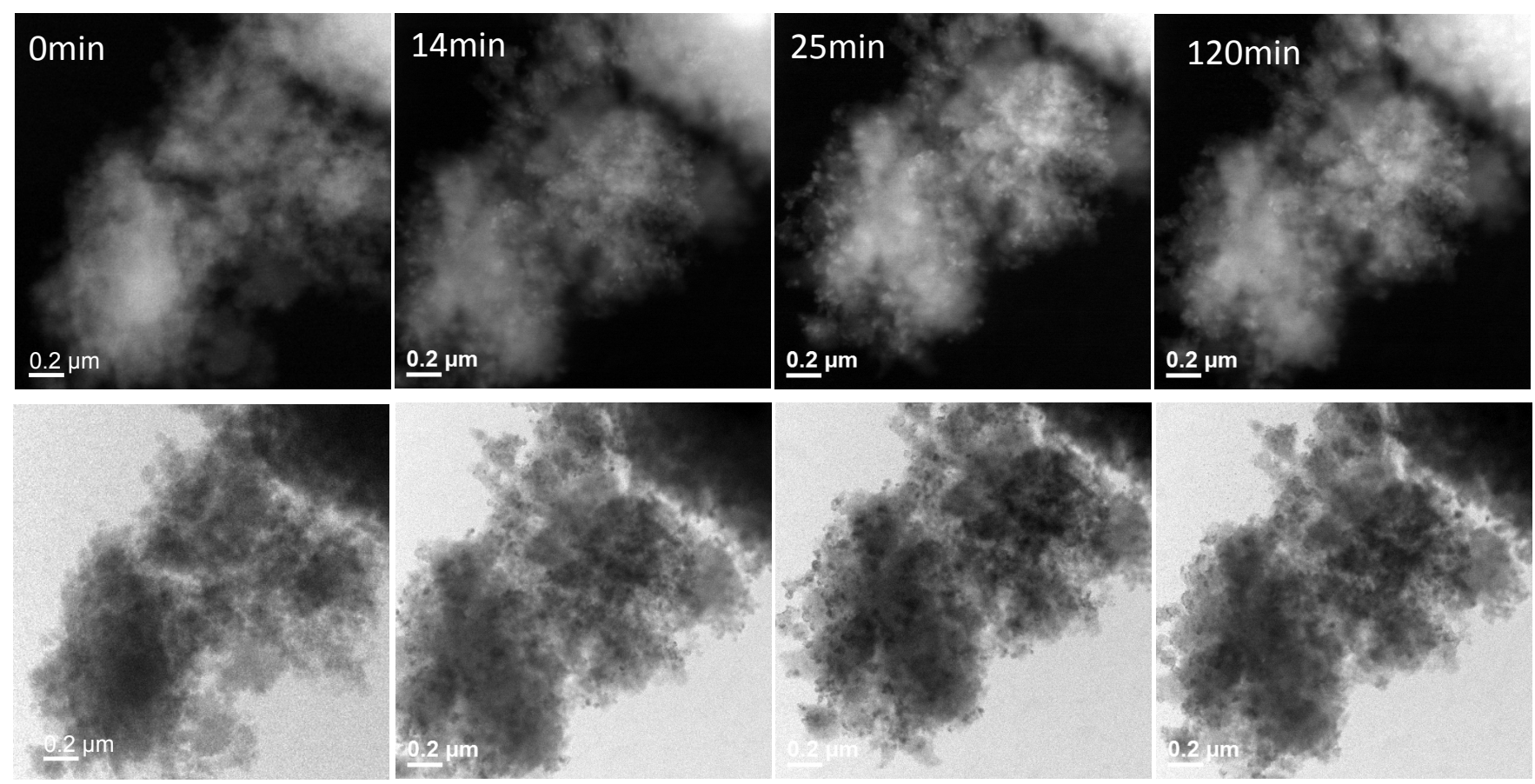

Figure 1. Time-lapsed (zero to 120min.) HAADF-STEM and simultaneously acquired BF-STEM images showing redation behavior of calcined $\mathrm{Cu} / \mathrm{BEA}$ at $300^{\circ} \mathrm{C}$ in flowing $4 \% \mathrm{H}_{2} / \mathrm{Ar}, 720$ Torr.
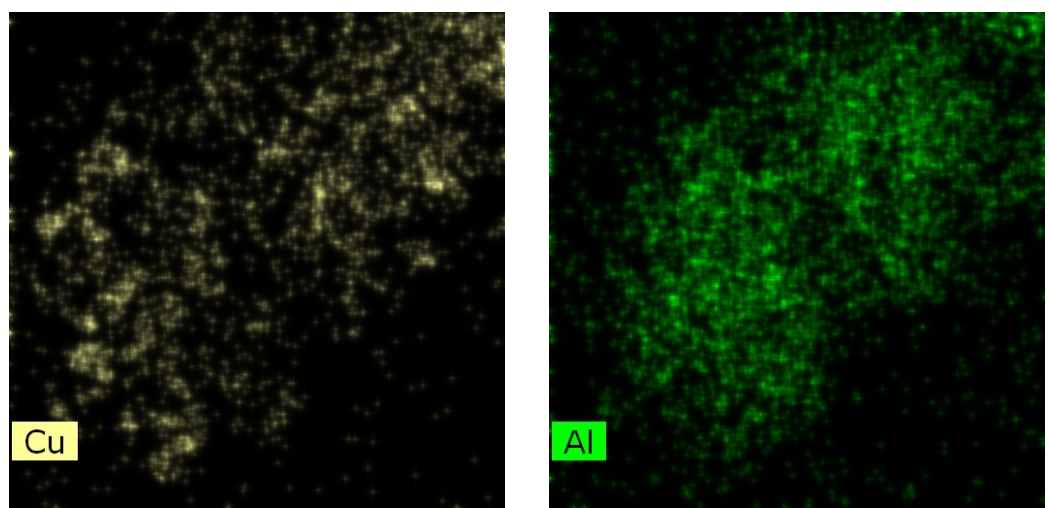

Figure 2. $\mathrm{Cu}$ and $\mathrm{Al}$ elemental maps for the $\mathrm{Cu} / \mathrm{BEA}$ particle shown in Figure 1 at $300^{\circ} \mathrm{C}$ in flowing $4 \mathrm{H}_{2} / \mathrm{Ar}$ and 720 Torr after reaching $120 \mathrm{~min}$. of in situ S/TEM reduction reaction. 